Buradzhiev, K. (2022). Bulgarian musical folklore in the creativity of the composer Ivan Spasov. The performing technique of Rumen Sirakov. Culture and arts in the context of world cultural heritage. Klironomy, 1 (4), 75-81. Ostrava: Tuculart Edition. (in Bulgarian)

Бураджиев, К. (2022). Българският музикален фолклор в творчеството на композитора Иван Спасов. Изпьлнителската техника на Румен Сираков. Culture and arts in the context of world cultural heritage. Klironomy, 1 (4), ___. Ostrava: Tuculart Edition.

DOI: $10.47451 / \operatorname{art} 2022-02-01$

The paper will be published in Crossref, Internet Archive, ICI Copernicus, Google Scholar, Academic Resource Index ResearchBib, JGate, ISI, eLibrary, Ukrainian National Library databases.

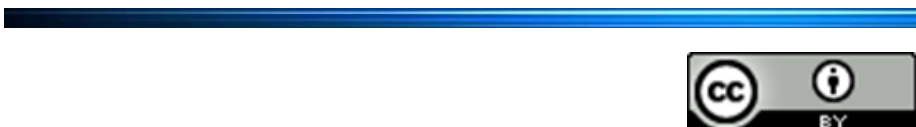

Kostadin Buradzhiev, Professor, Doctor of Musicology and Music Art, Vice rector "Learning activity", Academy of Music, Dance \& Fine Arts "Professor Asen Diamandiev", Plovdiv, Bulgaria.

\title{
Bulgarian musical folklore in the creativity of the composer Ivan Spasov
}

Abstract: The national folklore wealth of Bulgaria is great. Today, the Institute of Musicology at the Bulgarian Academy of Sciences stores more than 260,000 Bulgarian folk songs, about 30,000 folk melodies, over 4,000 dance instrumental melodies, about 6,000 filmed folk dances and customs accompanied by music, the Bulgarian National Radio has recordings with Bulgarian folk music, of which 3,000 titles are authentic, unprocessed music, etc. An analysis of the works of Bulgarian composers clearly outlines their different approach in their work with Bulgarian musical folklore. Their activity, in its entirety, has significantly contributed to the development of processing and original music based on folklore. Each of the examined composers outlines his own path in the development of the genre, giving a new direction to the young composers. The study object is folklore in songwriting by the composer Ivan Spasov. The study purpose is to research some of the folklore-based songs and their significance for the development of choral art in Bulgaria. The main methods used in the study are comparative analysis and synthesis. Approach them in a theoretical-cognitive, analytical aspect, the basis of the price of synthesis between poetry and music.

Keywords: composers, musical folklore, compositional technique, songs for choir.

Костадин Бураджиев, професор, Аоктор по музикология и музикално изкуство, Заместник ректор „Учебна Аейност“, АкаАемия за музикално, танцово и изобразително изкуство, “Проф. Асен Аиамандиев” - Пловдив, Пцовдив, Бъцгария.

\section{Бъмгарският музикацен фолкмор в творчеството на композитора Иван Спасов}

Резюме: Националното фолклорно богатство на Бъцгария е голямо. Анес в Института по музикознание при Българската Академия на Науките се съхраняват повече от 260.000 български народни песни, около 30.000 народни мелодии, наА 4.000 танцови инструментални мелодии, около 6.000 филмирани народни танци и обичаи, придружени с музика, Бъцгарското Национално РаАио притежава записи с българска народна музика, от която 3.000 заглавия са на автентична, необработена музика и т. н. (Брамованова-Станчева, 1981:11-12). Чрез анализ на творчеството на бъмгарските композитори ясно се очертава различният им подход в работата им с българския музикален фолкАор. 
Аейността им, в своята цялост, е Аопринесла значително за развитието на обработката и авторската музика на фолклорна основа. Всеки един от разгледаните композитори очертава собствен пьт в развитието на жанра, Аавайки нова насока на младите композитори. Обект на настоящото изследване е фолклора в песенното творчество на композитора Иван Спасов. Цел - Аа изследвам част от песните на фолклорна основа и значимостта им за развитие на хоровото изкуство в Бъцгария. Основните методи, използвани в изследването са сравнителен анализ и синтез. Подходите кьм тях са в теоретикопознавателен, аналитичен аспект, основаващ се на синтеза между поезия и музика.

Ключови думи: композитори, музикален фолклор, козпозиционна техника, песни за хор.

\section{Въведение}

След Освобожлението от турско робство, младата българска Аемократична общност е искала по-бързо и по-дъ ббоко Аа опознае изкуството и културата на европейските народи, вземайки всичко, което е необходимо и имащо значение в определения исторически момент. Същевременно е било и огромно желанието Аа се покаже на света най-голямото национално богатство - самобитната бъцгарска народна песен, многогласно претворена и обогатена от първите музикацни творци, в опората на която те виждат разцвета на бъцгарската музика.

Националната, „народностна миния“ проявява забележителна устойчивост и се превръща в трайна тенленция за професионално музикално творчество. Съчетаването и със стремежа към овладяване Аостиженията на европейската музика довежАа до създаването на майсторски образци във всички музикацни жанрове, на основата на богатите ни музикалнофолклорни традиции. (Г. Попова 2005)

Обект на настоящото изследване е фолклора в песенното творчество на композитора Иван Спасов.

Цем - да изследвам част от песните на фолклорна основа и значимостта им за развитие на хоровото изкуство в България.

За постигането на тази цел конкретизирам следните задачи:

- Живот и творчество на композитора;

- Специфични похвати в песенното творчество на Ив. Спасов;

- Значимост на песенното творчество на композитора.

Основните методи, използвани в изследването са сравнителен анализ и синтез. Подходите към тях са в теоретико-познавателен, аналитичен аспект, основаващ се на синтеза между поезия и музика.

Композиторът Иван Спасов е роден в София през 1934 година, но трайно свързва живота и творческата си дейност с Пловдив [1]. Той е еАна от най-авторитетните фигури в граАа, ярък представите н на съвременното българско творчество, и е човек, за който може Аа се каже, че музиката е единствено и неотменно призвание. 


\section{Основна част}

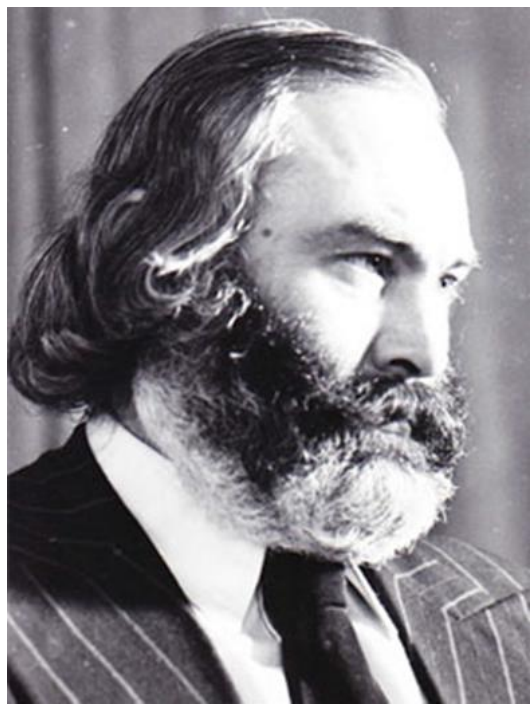

Фигура 1. Композиторьт Иван Спасов (1934-1996)

Композиторът Иван Спасов е роден в София през 1934 година, но трайно свързва живота и творческата си дейност с Пловдив [1]. Той е една от най-авторитетните фигури в граАа, ярък представител на съвременното българско творчество, и е човек, за който може да се каже, че музиката е единствено и неотменно призвание.

Срещата му с композитора Панчо ВАадигеров е повратен момент в неговия живот. Обучението при световноизвестния маестро става фундамент за по нататъшното му израстване като композитор. ОвцаАява до съвършенство не толкова правилата и механизма на композиционния процес, колкото някои важни принципни позиции по отношение на творческата реализация. Аичната свобода на средствата остава неограничена за постигане на виртуозна игра със звуковите комплекси и като стремеж за най-точно предаване същността на замисъ $\Lambda$.

Втори важен момент за младия композитор се явява обучението му по композиция във Варшава при Томаш Шикорски и Кшищоф Пендерецки. Във Варшава Спасов разбира, че съвременното творчество е способността на художника Аа мисли в съвременни категории, Аа настрои своя пулс към времето, в което живее.

1969 година бележи нов момент в творческото развитие на автора, със „Събор-надляване” за 22 Аухови инструмента. В тази творба Спасов свързва още по-тясно интонационните особености на българската народна музика с развитието на композиционната си техника, в което ясно Аичи отношението му към фолклора, но по-скоро като национална обагреност, като налагаща се атмосфера, отколкото трайна връзка с народопесенните интонации. Това най-ясно мичи в произведенията му „Авижения” за 11 струнни (1966), „Събор-надсвирване” (1969), „Бъмгарски напеви” (1968-1969). „Само изполвването на фолклорни елементи още не прави 
произведението начионално”- тази своя мисъц композиторьт творчески доказва през целия си живот.

Той е всепризнатият новатор при работата с фолкцорния материал - използване на нови технико-изпьлнителски изразни среАства, характерни за съвременната българска музика; нови начини на изписване на партитурата; използване на опрелелени по-малки или поголеми ритмични модели, върху които се пее кантиленна мелодия, която обикновено е и основният напев на песента - автентичната народна мелодия. Това ясно кичи в неговите преки фолклорни образци - песните по народен текст („Мехметьо, севда голема”, „Женаразделнича", „Ава тъпана бият”, „Защо ма, майчо, не даде”), създадени през втората половина на

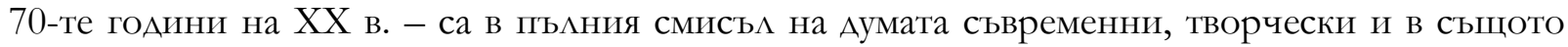
време - Аъцбоко национални образци на ярка художествена мисъ.

За песните на фолклорна основа на Иван Спасов Константин ИАиев пише: „Такова, свежо, оригинално, дълбоко, неизкушено от професионални спекулачии и същевременно майсторски професионално, като техника, пресъздаване на неподражаемия свят, който нашият музикален и поетичен фолклор носи, $е$ може би най-голямата творческа победа на композитора. Вярно почувствал психологията на пеещия българин, трансформачия на звука от ехото на балканите или безкрайната шир на полята, сочиалната сила на тази песен, сплотила и запазила нашия народ през годинте на тежките изпитания, са белезите, които поставят обработките на Иван Спасов на особено масто между стотичите подобни опити. С дълбокото проникване в звучащата душа на българина и много далеч, както по време, така и по техника и естетика, Спасов е друга творческа индивидуалност, друго поколение." (Илиев, 1981)

Неговият стилово-индивидуален универсален тип техника е алеаториката, като индивидуален начин на изразяване. Нейният основен принцип - случайността, успешно кореспондира с някои похвати от народното многогласие: хетерофония, нестабилно Авижение на бурдонния глас, острите секундови съчетания при диафонията и Ар. Разчупвайки все пак стеснените рамки на народния хор, той постига народностна звукова атмосфера посредством полифонично съпоставяне на самостоятелно и различно протичащи в метроритмическия параметьр мелодически минии. Тази композиционна техника бе възприета от редица по-млади автори, които много умело я използват не само в песни за народен хор, но и произведения за народен оркестьр.

Иван Спасов за първи път в българската музика на фолклорна основа (1972 г.) прилага съвременни композиционни похвати при работа с фолклорния песенен материал в песента „Мехметьо, севда голема”. Той има предпочитание към народните песни с драматични текстове - „Аимано, либе Аимано”, „Айшико, пиля шарено”, „Азминко” и Ар. Неслучайно Араматичните солови партии често пъти звучат като оплакване. В тези песни срещаме съзнателния отказ на автора от месните ходове, превръщането им в ритуали, Арами, които провокират слушателя. „Една рафинирана и сложна композиторска техника ни отвежда към напреднали стадии на алюзията за пълно сливане на музиката с афектния говор”, така определя песните на Спасов Ценка Йорданова (Йорданова, 1984). Аа вземем типичното за Спасов разлагане на песенната материя (Мехметьо, севда голема) на Ааконични мотиви и тяхното алеаторно наслагване - метоА, който се превръща в интензивна структурообразуваща сила. Подобни похвати могат да се видят и 
в началните епизоди на други негови песни - „Ава тъпана бият”, „Жена-разделнища”, „Защо ма, майчо, не даде”, за разлика от „Аа ти са падни, майчу” и „Айшинка”. На прегледа „Нова българска музика “84” творбата на Иван Спасов „Маринко, мое дощерьо” се приема като нова страница в неговото творчество и дава повод за размишления върху третирането на народната тема в авторската музика. Затова песента е приета като нова, неочаквана за автора творческа сполука (Тодоров, 1984).

Посредством съвременните композиционни похвати - серийна техника и алеаторика, песните му разрешават огромна свобода по отношение на интерпретацията. Принципът на контрастност той търси най-вече в отношенията бързо-бавно, тихо-силно, статичноАинамично, противопоставяне на тембри и др., и може Аа се забележи във всичките му песни. Самият Спасов сам определя песните си за народен хор като съвременни бъ гарски хорови песни на фолклорна основа, както и това, че той не робува на „изискванията” на специфичното за отлелните фолклорни области. „Аз пиша музика, а не трактат - в 99\% от случаите съм търсил драматико-трагичното звучене, човешката драма, драмата на отделната личност, а не начията като ияло." (Ангелов, 1994)

Иван Спасов определя песните си за народен хор не като „обработки”, а “хорови песни по народни текстове (Спасов, 2004). Словото, както пише изследователят на музиката на Иван Спасов Ангел Ангелов (Ангелов, 1994:143), е организиращ елемент в песните му. То определя и техническите средства, които са в услуга на художествените намерения на композитора. „Винаги отделям по-голямо внимание на смисловото сьдржание на текста, даже търся възлови, „Фатални" думи. Всеки език има своите особености, които композиторът е длъжен да познава, когато става въпрос за претворяването им в музиката."

Композиторьт Константин ИАиев, говорейки за хоровата песен казва, „че след Аобри Христов и Аюбомир Пипков, песните на Спасов са нов, трети етап в развитието на българската хорова музика." (Ангелов, 1994) Използването на сонорни и алеаторни похвати, импровизации, кльстери, „ехо”, полифония, Аостигаща на места Ао 12 гласа, индивидуалния композиционен маниер в творбите му „Аа ти са падне, майчо”, „Радо, бела Радо”, „Женаразделнича" и „Защо ма, майчо, не даде” трудно биха го опрелелили като автор на обработки в тесния смисъц на думата. А последната песен на композитора „Хубава Мавруда” би слисала всяко международно жури [2] (Фиг. 2). В тази творба авторството е наццеляло наА фолклорното начало.

Самият композитор признава, че не се чувства фолклорист и че не е „изуиавал” научно българския музикален фолклор. И макар песните да звучат напълно естествено, фолклорно, автентичният материал, който композитора използва е минимален. Най-често оригиналната мелодия се изпява в средата на песента. Всичко останало е авторско, в характера на народната песен и характерните фолклорни прийоми. И все пак Спасов е голям познавач както на народната песен, така и на изпь нителските възможности на човешкия глас, за него той е най-съвършеният инструмент. „Под съвършен разбирам не неговите технически възможности, не диапазона му, а способността му да изразява най-фините, най-дикретните нюанси на човешкото чувство, способността да постига дълбочина на преживяването, каквато дори и най-знаменитият 
инструменталист-изиълител не може да постигне." (Ангелов, 1994:141) Свободата в процесуалното разлагане на звуковата илея и в боравенето с тембъра дават онази възможност за различни творчески решения. Но единствено алеаториката се свързва с мисълта му на национален композитор. Самият строеж на народната песен предполага многопластово изграждане, каквото в определен смисъл представцява алеаториката.

Изключителното творчество на композитора Иван Спасов значително изпреварва развитието на жанра на обработката на народната песен, но оказва силно въздействие със своята Аична и Аъцбоко сакрална естетика с неоткцонно постоянство и никакъв морален и творчески компромис, постоянно тьрсещ хармония межАу чисто земното и Ауховното, межАу скромността и достойнството. За първи път български фолклорни елементи съжителстват, органически претопени в една модерна форма, проведени с една абсолютно съвременна композиционна техника.

Накрая искам да завърша с думите на Иван Спасов: „Може би последната ми композичия ще бъде само един единствен тон. Аано да бъде красив тон. Ако остане нещо от мен, от моята музика - дори една песен, една молитва - ще бъда щастлив да наблюдавам Оттам.” (Спасов, 1995)

\section{ОбсужАение}

Националното ни песенно фолклорно наследство е огромно. Не малка част от фолклорните ни песни, обработени от най-талантливите ни композитори, станаха Аостояние на света чрез народните ни хорове, съзАавайки явлението мистерия на българските гласове. Всъщност, хармонизирането на народните мелодии като кично творчество е продъцжаване на фолклорните ни традиции. Развитието на жанра „Народни хорове и ансамбли“" през последните 70 години дава възможност за обширно изследване на процесите в него. Естествено изследването задъцжително трябва да обхваща два компонента българският музикален фолклор и творчеството на българските композитори. Чрез анализа на творчеството им ясно ще се очертае различния подход в работата с фолклорния материал.

\section{Заключение}

Песенното творчество на фолклорна основа на композитора Иван Спасов е само част от огромното му творческо. В изследването ясно се очертават основните композиционни похвати прилагани от композитора в песните му, използването на алеаторика и полифония за определено Араматургично изграждане и преврыщане на обработката на народната песен в авторско произведение.

Изключителното творчество на композитора Иван Спасов значително изпреварва развитието на жанра на обработката на народната песен, но оказва силно въздействие със своята Аична и Аъцбоко сакрална естетика с неоткцонно постоянство и никакъв морален и творчески компромис, постоянно търсещ хармония между чисто земното и Ауховното, между скромността и достойнството. 


\section{Източници на информация:}

Ангелов, А. (1994). 60 стъпки по пътя към Храма. ИК „Хермес”.

Баларева, А. (1992) Хоровото дело в България. ИзА. БАН.

Брашованова-Станчев, Аада (1981). Българската народна музика и нейното композиторско иретворяване. София: АИ „Народна просвета““.

Вълчинова-Чендова Ец. (2004) Пътат към фолклора - възможен път за търсене на творческа идентичност. Националната илея в европейското музикално творчество през ХХ век”. Сборник. Шумен.

Илиев, К. (1981). Аитературен глас, бр. 7.

Йорданова, Ц. (1984). Алхимията на песента. Кн. 1. Бъцгарска музика.

Попова, Г. (2005) За някои проблеми на хорово-диригентската практика, във връзка с българската народна песен, създадена под влияние на фолклора. Сборник научни доклади. АУ БлагоевграА.

Спасов, И. (2004). Изповед на един композитор. Пцовдив: ИК „Жанет 45”.

Спасов, И. (1995). Музика. Вчера. Анес. Кн. З. Бъмгарска музика.

Тодоров, Т. (1978) Съвременност и народна песен. Издателство Музика.

Тодоров, Т. (1984). Към фолклора - сразлични подходи. Кн. 5. Българска музика.

\section{Примечания}

[1] Вчера. Анес” (кн. 3, 1995) на въпроса „Винаги сте стояли Аалеч от „центьра” - от София, от Музикалната академия в София, от Съюза на българските композитори, защо е така? Имате ми нещо против „центьра”?” Иван Спасов разказва: „Никога не съм се стремял съзнателно Аа стоя Аалеч от „центъра”. Просто животът ми се стече така. Колкото до музикалната академия - някога, сигурно преди двадесет години, незабравимият 3Аравко Манолов, тогава беше Аекан, ме покани да водя курс по серийна техника. Проведох само Аве мекции, а по този повод ЗАравко едва не го уволниха. И до Аен Анешен единствено в Академията в Пловдив се изучава тази основна за съвременния музикант Аисциплина. И, с извинение, още малко по този въпрос: това, че съм стояц Аалеч от „центьра”, просто ме е предпазвало от безконечните котерийни борби за влияние, за мощ в Съюза на композиторите, в Радиото или Балкантон. Вместо да си губя времето в подобни боричкания, аз го използвах за самоусъвършенстване. Мисля, че сега ми завиждат за тази моя позиция. Нека им бъде простено."

[2] Това твърдение получи своето потвърждение на 5th World Choir Games проведени през 2008 г. в Грац, Австрия. Песента направи силно впечатление на жури и публика. Тя беше една от четирите конкурсни песни, с които се представи на този най-голям в света хоров конкурс Академичният народен хор при АМТИИ с Аиригент проф. А-р КостаАин Бураджиев, спечелвайки първия за България „ЗАатен меАал“ и званието „Световен шампион“ в категория „Фолклор“. 


\section{Приложение}

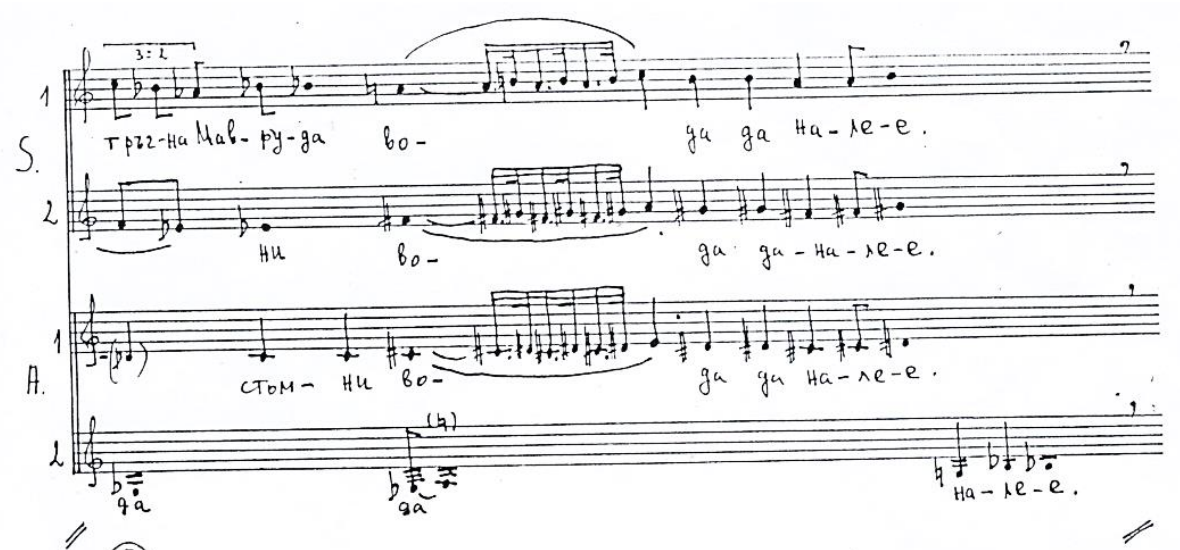

(5)
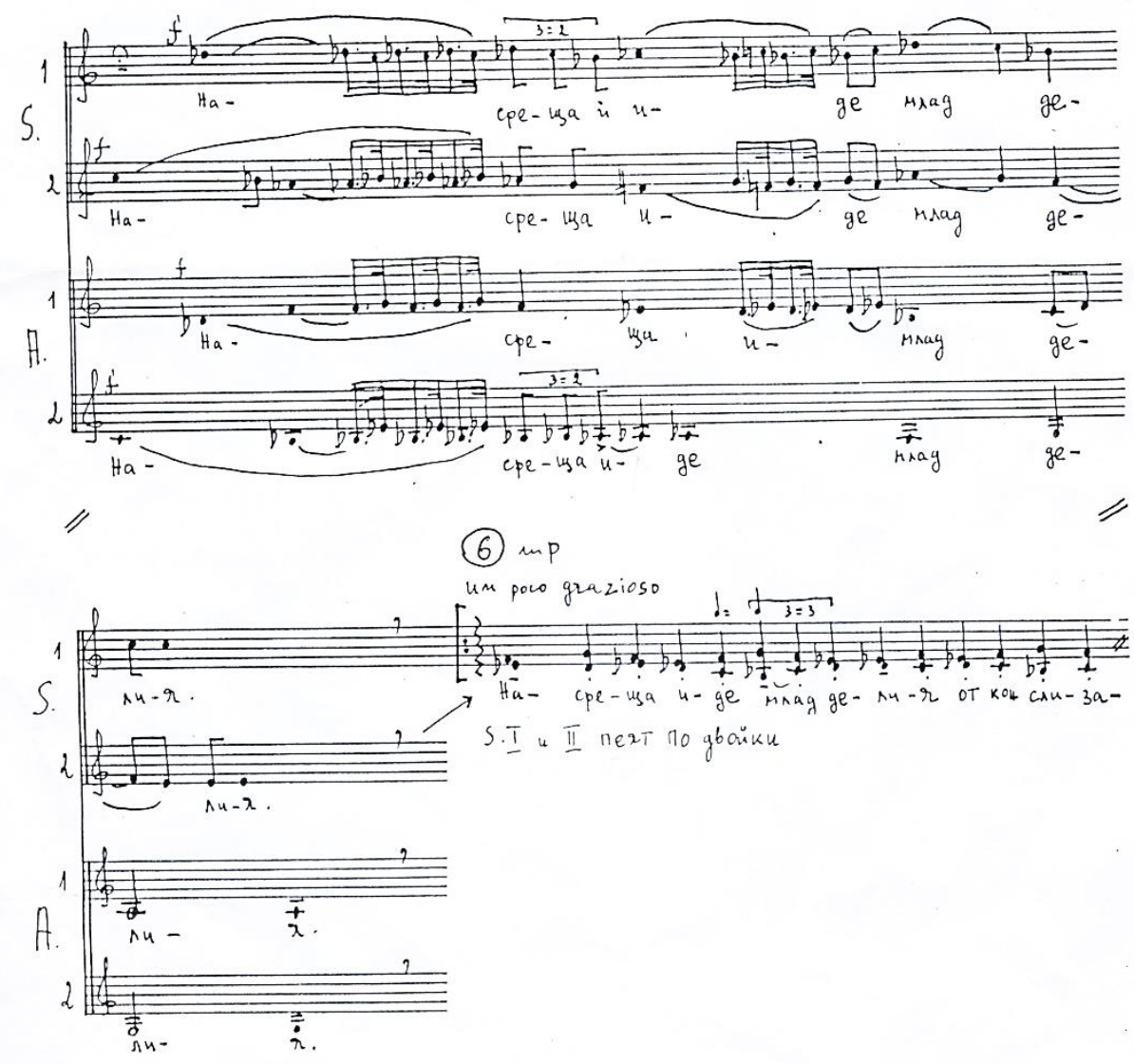

Фигура 2. Факсимице от песента "Хубава Мавруда" 